\title{
下顎のタッピング運動に協調した頭部運動の多点解析の試み
}

\author{
河野世佳, 土田幸弘, 河野正司, 荒井良明, 湊 修, 蔵本 誠, 松山剛士 \\ 新潟大学歯学部歯科補緅学第一講座 (主任：河野 正司 教授) \\ 〔受付：平成10年 7 月 27 日〕
}

\section{A preliminary study of coordinated head and mandibular tapping movements through analysis of multi-reference points}

\author{
Tsuguyoshi Kohno, Yukihiro Tsuchida, Shoji Kohno, Yoshiaki Arai, Osamu Minato, \\ Makoto Kuramoto, Takeshi Matsuyama \\ Department of Removable Prosthodontics, School of Dentistry, Niigata University
}

(Director: Prof. Shoji Kohno)

[Received: July 27, 1998.]

Key words: jaw movement, head movement, tapping movement, cooperative movement, multi-reference point analysis

\begin{abstract}
We have previously demonstrated that the head moves rhythmically and coordinately with the mandible during functional mandibular movements; however, in those studies we could not provide information on the movement of the head as a whole because only the mandibular and maxillar incisal points were tracked. The objective of the present study was to assess sagittal head movement through analysis of the vectors of several reference points in the head and a mandibular incisal point during open-close tapping movements of different frequency.

The same 6-degree-of-freedom measuring device employed in our previous studies was used again to analyze data from four male adults, age 26-27 years old.

Results:

1 ) During mandibular tapping movement, head reference points moved in a rotation-like movement; i.e., during opening the head moved clockwise and counter-clockwise during closing in the left side's sagittal plane.

2 ) There were no significant differences of angulation of the vectors between $1 \mathrm{~Hz}$ tapping movement and $3 \mathrm{~Hz}$ in all reference points. However, the range of motion of all reference points depended on the frequency of tapping movements in this case. The motion of the $1 \mathrm{~Hz}$ tapping movement was larger than the $3 \mathrm{~Hz}$ one.

3 ) The hypothetical rotation center was located above the cervical vertebrae, and its sagittal position was dependent on each tapping movement.
\end{abstract}

抄録 我々はこれまで下顎の咀緭運動時やタッピング運動時に頭部が下顎と協調してリズミカルに運動す ることを報告してきた．しかしいずれの報告も上下顎の切歯点を分析対象としたものであり，頭部全体の 運動を説明するには至っていない. 
そこで著者らは矢状面内におけるタッピング運動時の頭部の運動様相を把握する目的で頭部に複数の分 析点を設け，それらの点の運動方向，運動距離を計測することによって，頭部運動の解析を試みた.

測定には 6 自由度顎運動測定装置を用い，頭部を固定することなく行った．被験者として自覚，他覚的 に顎口腔系に異常を認めない26〜27歳の本学男子大学院生 4 名を選択しタッピング運動を負荷した.

その結果を以下に示す。

1. タッピング運動の際，矢状面観で，頭部は下顎開口時に上顎切歯点が下顎切歯点と離れるよう後屈方 向に，閉口時にはこれらが近づくように前屈方向にと回転運動を行っていることが明らかとなった。

2. 頻度 $1 \mathrm{~Hz}$ のタッピングでは頻度 $3 \mathrm{~Hz}$ のタッピングより各分析点の運動距離は有意に大きいが, 運動 方向に有意差は見られなかった。

3. 頭部回転運動の中心探索の結果, タッピング運動の開口相において頭部運動の回転中心は, 頸椎の上 方の体軸上に分布しており，この位置はタッピング頻度と関係のあることが示唆された。

\section{I. 緒 言}

顎運動は下顎の運動とこれに伴う頭部の協調運動によ って行われている゙といわれているが，これまで実証的 な報告はなかった。そこで我々は，上顎および下顎任意 点の運動をそれぞれ 6 自由度で解析する手法を開発し， 下顎機能運動時における頭部の協調運動の存在を明らか にしてきた ${ }^{2-4)}$ 。まだ，顎機能障害症例:では頭部の協調 運動が正常者と異なる様相を示し，頭部運動が下顎の機 能運動の円滑な遂行に欠かせない随伴運動である ${ }^{51}$ と考 えられるようになってきた.

しかし，これまでの頭部運動に関する報告は，上顎切 歯点のみを対象としたものであり，頭部全体の運動を把 握するためには, 複数点についての解析が不可欠であ る.

そこで今回，頭部矢状面上の多点解析を新たに行うこ とによって, タッピング運動時の矢状面内における頭部 の動きを把握する事を目的とした測定と解析の可能性を 探ることとした.

\section{II. 研究方法}

\section{1. 被験者}

顎口腔系に既往歴がなく，現在も自覚的ならびに他覚 的に異常を認めず，本実験の意義を十分理解して協力を 得ることのできた $26 〜 27$ 歳の本学男子大学院生 4 名とし た.

\section{2.下顎運動および頭部運動の測定法}

頭部無拘束状態で 6 自由度顎運動測定装置（東京歯材 社製 TRIMET）を使用し，下顎運動と頭部運動の同時記 録を行った ${ }^{6)}$. 被験者には，座位にて，頭部カンペル平 面を床とほほ水平に自力で保たせ，頻度 $1 \mathrm{~Hz}$ なら゙に
$3 \mathrm{~Hz}$ のタッピング運動を10秒間負荷した。得られたデ 一タのうち頭部運動，下顎運動とも，大地を基準とした 座標系に対するデー夕を使用し, 矢状面からの解析を行 った。な㧍頻度の規定はメトロノームを用いた聴覚フィ ードバックによって行い, 開口量はできる限り大きく行 うよう指示した。

\section{3. 分析方法}

1) 分析点

頭部矢状面投影図上において，以下のように $5 つ の$ 分析点を設定した。顎運動の分析点として下顎切歯点 （I L ）を, 頭部運動の分析点としては, 上顎切歯点 （IＵ）とその他に新たに 3 つの分析点を設定した。す なわち, 頭部における左側平均的顆頭点相当部を顆頭部 （C）とし，Cを通りカンペル平面に対する鉛直軸上で $\mathrm{C}$ の $90 \mathrm{~mm}$ 上方の点を頭頂部 $(\mathrm{P})$ ，さらにこの鉛直軸 に対するIUの対称点を後頭部（O）とした（図 1).

2 ) 分析対象

タッピング運動の開始から10秒間の運動データのう ち, 下顎運動の開口量, 頻度共に安定している連続した 5 ストロークのタッピング運動を, 解析に用いた（図 $2)$.

3 ) 計測方法

下顎及び頭部分析点の運動の一例を矢状面投影図にて 図 3 に示す. 図中の黒い矢印は開口運動時の，白抜きで 示した矢印は閉口運動時の各分析点の運動方向を示して いる．各分析点が一定の方向に運動しながら，軌跡を描 いていることが認められる。 そこで図 4 のごとく開口時 に見られる各分析点の運動軌跡について，運動経路と最 多数点で接する直線（1）を引き，1 と大地とのなす角 度を運動方向 $(\theta)$ として測定した， $\theta$ の正負は，大地 に対して水平な面を基準面とし，被験者に対する仰角を 正の方向, 俯角を負の方向として示した。さらに1に垂 
直で軌跡の起点と交わる直線を $(\mathrm{m})$, 同じく 1 に垂直 で軌跡上の点と交わりかつ $\mathrm{m}$ から最も離れた直線を $(\mathrm{n})$ とし， $\mathrm{m}$ と $\mathrm{n}$ の距離を運動距離 $(\mathrm{d})$ とした，以上のよ うな方法で各分析点における運動をストロークごとに評 価した。また，タッピング頻度の違いによる各分析点の

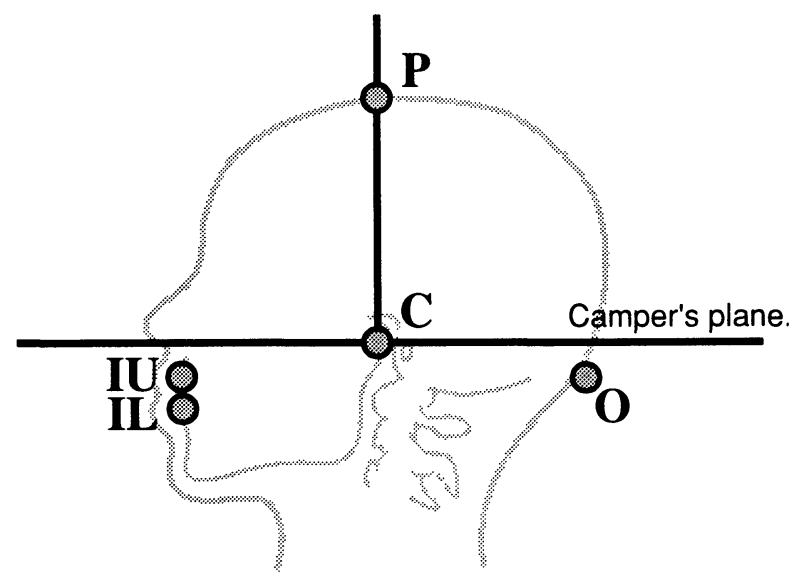

図 1 分析点

I U : 上顎切歯点 I L : 下顎切歯点 $\mathrm{C}$ : 顆頭部 $\mathrm{P}$ : 頭頂部 $\mathrm{O}$ : 後頭部

Fig. 1 Reference points
I U : Maxillary incisor point
I L : Mandibular incisor point
$\mathrm{C}$ : Condylar point $\mathrm{P}$ : Parietal point
$\mathrm{O}:$ Occipital point

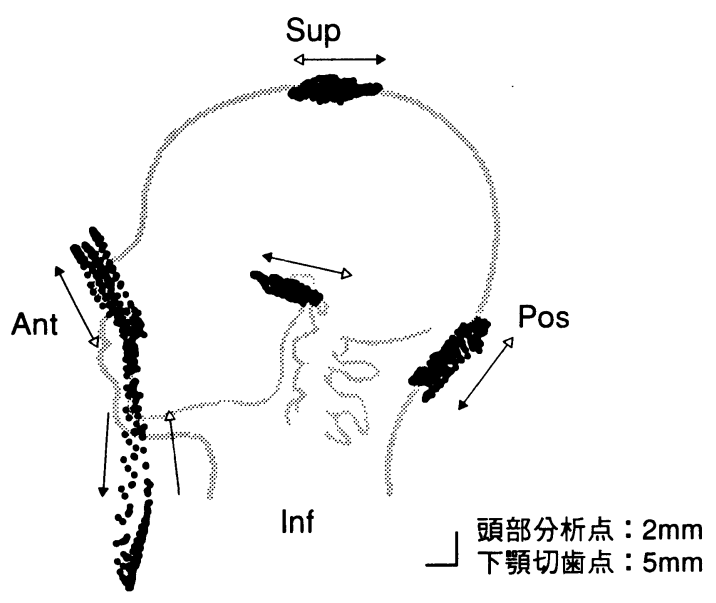

図 3 各分析点の運動軌跡

$$
\text { (Sub.B 3Hz tapping) }
$$

Fig. 3 Movements of mandibular and head reference points
運動方向 $\theta$, 運動距離 $\mathrm{d}$ の值は Student $\mathrm{t}$-検定にて統計 処理を行った。

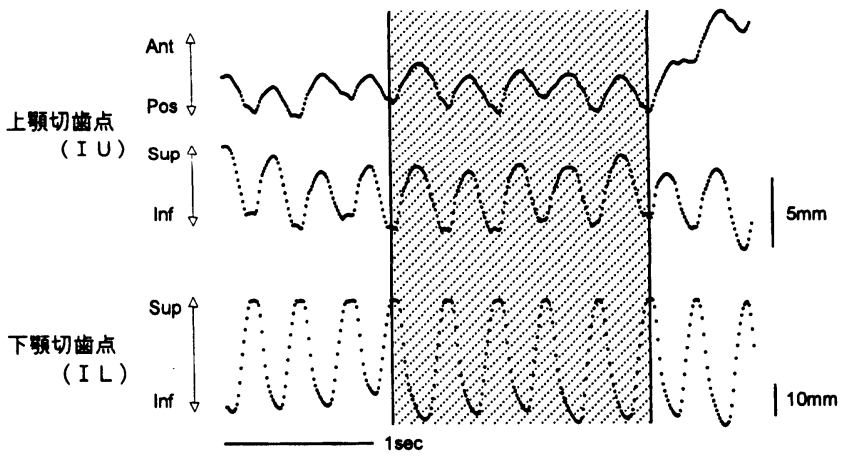

図 2 分析対象

タッピング運動上下顎切歯点時系列デ

ータ中で, 斜線部を分析対象とした (Sub.B $3 \mathrm{~Hz}$ tapping)

Fig. 2 Sample traces of the maxillary and maudibular incisor points' tracking. The upper trace shows the vertical and anteroposterior components of the maxillary incisor's movement; the lower trace shows the vertical component of the mandibular incisor point. The five strokes within the shaded area were selected for analysis.

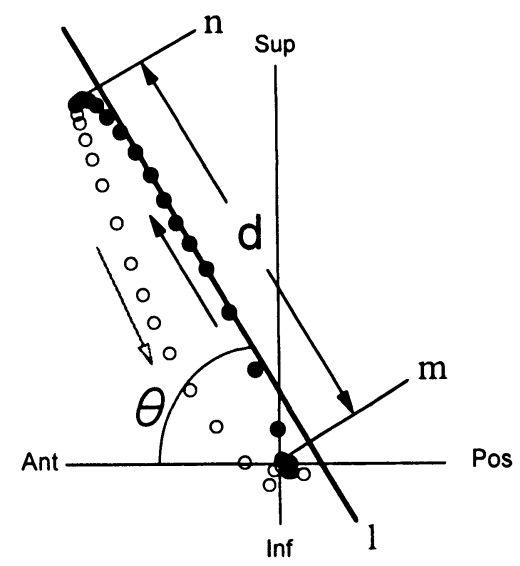

図 4 運動軌跡の計測部位

$\mathrm{d}:$ 分析点の運動距離

$\theta:$ 運動方向

○: 開口相 $\bigcirc$ : 閉口相

Fig. 4 Analysis of the vector of each reference point

$\mathrm{d}$ :reference points' range of motion $\theta$ :angle of trajectory

O: opening phase $\bigcirc$ : closing phase 


\section{III. 結 果}

\section{1．上顎切歯点｜Uと下顎切歯点｜Lの関係}

1) 運動方向 $\theta$ について

I Uの運動方向 $\theta$ は被験者 4 人のそれぞれのタッピン グ運動における平均值では46〜66度の範囲にあり, 開口 時に前上方に運動していることがわかる．また，タッピ ング頻度ごとに 4 人の被験者の平均值をみると頻度 1 $\mathrm{Hz}$ では59.4度， $3 \mathrm{~Hz}$ で55.3度と大きな違いはなかった。 しかし各タッピングにおいて運動方向 $\theta$ の標準偏差を見 ると，1 Hzでは4.3〜18.7，3 Hzでは1.6〜11.1の範囲に

表 1 各分析点におけるタッピング頻度別の 運動方向「 $\theta\rfloor$

Table 1 Direction of reference points in each subject, according to tapping frequency

\begin{tabular}{|c|c|c|c|c|c|c|c|c|c|c|}
\hline & \multicolumn{5}{|c|}{ タッピング頻度 $1 \mathrm{~Hz}$} & \multicolumn{5}{|c|}{ タッピング頻度 $3 \mathrm{~Hz}$} \\
\hline & IL & IU & C & $\mathrm{P}$ & 0 & LL & IU & C & $\mathrm{P}$ & 0 \\
\hline $\begin{array}{c}\text { Sub.A mean } \\
\text { SD }\end{array}$ & $\begin{array}{r}-93 \\
0.9\end{array}$ & $\begin{array}{r}64 \\
5.0\end{array}$ & $\begin{array}{r}12 \\
5.6\end{array}$ & $\begin{array}{r}187 \\
3.8\end{array}$ & $\begin{array}{r}-50 \\
9.2\end{array}$ & $\begin{array}{r}-92 \\
1.6\end{array}$ & $\begin{array}{r}57 \\
7.0\end{array}$ & $\begin{array}{r}-16 \\
7.1\end{array}$ & $\begin{array}{r}200 \\
6.1\end{array}$ & $\begin{array}{r}-64 \\
8.7\end{array}$ \\
\hline $\begin{array}{c}\text { Sub.B mean } \\
\text { SD }\end{array}$ & $\begin{array}{r}-93 \\
1.6\end{array}$ & $\begin{array}{r}66 \\
4.3\end{array}$ & $\begin{array}{r}30 \\
10.5\end{array}$ & $\begin{array}{r}167 \\
6.4\end{array}$ & $\begin{array}{r}-69 \\
6.5\end{array}$ & $\begin{array}{r}-96 \\
1.5\end{array}$ & $\begin{array}{r}65 \\
1.6\end{array}$ & $\begin{array}{r}29 \\
5.4\end{array}$ & $\begin{array}{r}160 \\
8.9\end{array}$ & $\begin{array}{r}-48 \\
5.2\end{array}$ \\
\hline $\begin{array}{c}\text { Sub.C mean } \\
\text { SD }\end{array}$ & $\begin{array}{r}-102 \\
3.1\end{array}$ & $\begin{array}{r}57 \\
18.7\end{array}$ & $\begin{array}{r}32 \\
42.7\end{array}$ & $\begin{array}{r}140 \\
71.5\end{array}$ & $\begin{array}{r}-30 \\
15.1\end{array}$ & $\begin{array}{r}-95 \\
2.1\end{array}$ & $\begin{array}{r}53 \\
2.5\end{array}$ & $\begin{array}{r}19 \\
8.8\end{array}$ & $\begin{array}{r}153 \\
18.8\end{array}$ & $\begin{array}{r}-38 \\
11.6\end{array}$ \\
\hline $\begin{array}{c}\text { Sub.D mean } \\
\text { SD }\end{array}$ & $\begin{array}{r}-91 \\
4.2 \\
\end{array}$ & $\begin{array}{r}50 \\
8.8 \\
\end{array}$ & $\begin{array}{r}21 \\
12.8 \\
\end{array}$ & $\begin{array}{r}177 \\
5.6 \\
\end{array}$ & $\begin{array}{r}-39 \\
4.0 \\
\end{array}$ & $\begin{array}{r}-96 \\
1.8 \\
\end{array}$ & $\begin{array}{r}46 \\
11.1 \\
\end{array}$ & $\begin{array}{r}17 \\
11.0 \\
\end{array}$ & $\begin{array}{r}99 \\
91.8 \\
\end{array}$ & $\begin{array}{r}-34 \\
22.2 \\
\end{array}$ \\
\hline $\begin{array}{c}\text { mean } \\
\text { SD }\end{array}$ & $\begin{array}{r}-95.0 \\
5.1\end{array}$ & $\begin{array}{l}59.4 \\
11.9\end{array}$ & $\begin{array}{l}24.0 \\
22.7\end{array}$ & $\begin{array}{l}167.6 \\
37.7\end{array}$ & $\begin{array}{r}-46.8 \\
17.3\end{array}$ & $\begin{array}{r}-94.5 \\
2.2\end{array}$ & $\begin{array}{r}55.3 \\
9.3\end{array}$ & $\begin{array}{l}12.3 \\
19.1\end{array}$ & $\begin{array}{l}153.0 \\
56.8\end{array}$ & \\
\hline
\end{tabular}

表 2 各分析点におけるタッピング頻度別の 運動距離「d」

Table 2 Amplitude range of motion of reference points in each subject, according to tapping frequency

\begin{tabular}{|c|c|c|c|c|c|c|c|c|c|c|}
\hline & \multicolumn{5}{|c|}{ タッピング頻度 $1 \mathrm{~Hz}$} & \multicolumn{5}{|c|}{ タッピング頻度 $3 \mathrm{~Hz}$} \\
\hline & IL & IU & $\mathrm{C}$ & $\mathrm{P}$ & 0 & IL & IU & $\mathrm{C}$ & $\mathbf{P}$ & 0 \\
\hline $\begin{array}{c}\text { Sub.A mean } \\
\text { SD }\end{array}$ & $\begin{array}{r}37.1 \\
0.7\end{array}$ & $\begin{array}{l}8.7 \\
1.1\end{array}$ & $\begin{array}{l}2.2 \\
1.1\end{array}$ & $\begin{array}{l}6.3 \\
2.1\end{array}$ & $\begin{array}{l}7.7 \\
1.2\end{array}$ & $\begin{array}{r}22.9 \\
1.7\end{array}$ & $\begin{array}{l}2.3 \\
0.3\end{array}$ & $\begin{array}{l}1.0 \\
0.4\end{array}$ & $\begin{array}{l}1.3 \\
0.5\end{array}$ & $\begin{array}{l}2.6 \\
0.3\end{array}$ \\
\hline $\begin{array}{c}\text { Sub.B mean } \\
\text { SD }\end{array}$ & $\begin{array}{r}35.6 \\
1.1\end{array}$ & $\begin{array}{l}5.9 \\
0.7\end{array}$ & $\begin{array}{l}1.1 \\
0.7\end{array}$ & $\begin{array}{l}4.5 \\
1.3\end{array}$ & $\begin{array}{l}4.5 \\
0.6\end{array}$ & $\begin{array}{r}29.7 \\
1.8\end{array}$ & $\begin{array}{l}5.2 \\
0.7\end{array}$ & $\begin{array}{l}2.2 \\
0.5\end{array}$ & $\begin{array}{l}2.3 \\
0.5\end{array}$ & $\begin{array}{l}4.4 \\
0.4\end{array}$ \\
\hline $\begin{array}{c}\text { Sub.C mean } \\
\text { SD }\end{array}$ & $\begin{array}{r}52.8 \\
3.6\end{array}$ & $\begin{array}{l}9.2 \\
2.9\end{array}$ & $\begin{array}{l}5.2 \\
3.0\end{array}$ & $\begin{array}{l}4.7 \\
1.4\end{array}$ & $\begin{array}{l}7.3 \\
3.6\end{array}$ & $\begin{array}{r}21.6 \\
2.1\end{array}$ & $\begin{array}{l}2.1 \\
0.6\end{array}$ & $\begin{array}{l}0.9 \\
0.2\end{array}$ & $\begin{array}{l}0.8 \\
0.3\end{array}$ & $\begin{array}{l}1.4 \\
0.4\end{array}$ \\
\hline $\begin{array}{c}\text { Sub.D mean } \\
\text { SD }\end{array}$ & $\begin{array}{r}26.6 \\
2.1\end{array}$ & $\begin{array}{l}7.0 \\
2.1\end{array}$ & $\begin{array}{l}2.7 \\
0.8\end{array}$ & $\begin{array}{l}2.4 \\
1.3\end{array}$ & $\begin{array}{l}5.9 \\
1.6\end{array}$ & $\begin{array}{r}14.2 \\
1.5\end{array}$ & $\begin{array}{l}1.0 \\
0.3\end{array}$ & $\begin{array}{l}0.7 \\
0.4\end{array}$ & $\begin{array}{l}0.5 \\
0.4\end{array}$ & $\begin{array}{l}1.0 \\
0.4\end{array}$ \\
\hline $\begin{array}{c}\text { mean } \\
\text { SD }\end{array}$ & $\begin{array}{r}38.0 \\
9.9\end{array}$ & $\begin{array}{l}7.7 \\
2.2\end{array}$ & $\begin{array}{l}2.8 \\
2.2\end{array}$ & $\begin{array}{l}4.5 \\
2.0\end{array}$ & $\begin{array}{l}6.4 \\
2.3\end{array}$ & $\begin{array}{c}22.1^{*} \\
5.9\end{array}$ & $\begin{array}{l}2.7^{*} \\
1.7\end{array}$ & $\begin{array}{l}1.2^{*} \\
0.7\end{array}$ & $\begin{array}{l}1.2^{*} \\
0.8\end{array}$ & $\begin{array}{l}2.3^{*} \\
1.5\end{array}$ \\
\hline
\end{tabular}

あり タッピングの頻度が高くなると運動方向のばらつ きは減少してくることがうかがえる。

I Lの運動方向 $\theta$ に注目してみると， $\theta$ の範囲は平均 で-91〜-102度となり, 開口時にほほ鉛直下方に運動し ていることがわかる．また，タッピングの頻度別に比較 しても運動方向 $\theta$ に違いは見られなかった．標準偏差も 0.9 4.2と I Uに比較して小さくなっており，下顎運動 の方が頭部の運動よりもばらつきが少ないことがわか る.さらに標準偏差をタッピング頻度別に比較すると I $\mathrm{U}$ と同様に $3 \mathrm{~Hz}$ のタッピングの方が值が小さく，運動 方向のばらつきが小さいことが明らかとなった（表 1 ).

次に，描かれた運動軌跡から閉口時の運動様相を観察 した．開口運動時に I Uが前上方，I L が下方へと，互 いに離れる方向へと運動を行っていたのに対し，閉口時 のI Uは閉口開始点から後下方へ，I L は上方へと，互 いに近づく方向へと運動しているのが観察された。つま り閉口時には，I U， I L 共に開口時とは運動方向を逆 転しながら, 開口運動開始点の近傍へ戻る運動を行って いることが示された（図 5 ）。

\section{2 ) 運動距離 $\mathrm{d}$ について}

タッピング頻度 $1 \mathrm{~Hz}$ で I L の值は平均 $38.0 \mathrm{~mm}$ である のに対し I Uでは平均 $7.7 \mathrm{~mm}$ となり，I Uは I L の約 $20 \%$ の運動距離となった。同様に夕ッピング頻度 $3 \mathrm{~Hz}$ では運動距離 $\mathrm{d}$ は I L で平均 $22.1 \mathrm{~mm}, \mathrm{I} \mathrm{U}$ で平均 $2.7 \mathrm{~mm}$ となり，I U の運動距離は I L の約 $12 \%$ となった。 このように, タッピング頻度が高くなると, 頭部の運動 距離は下顎運動に比較して相対的に小さくなることが示

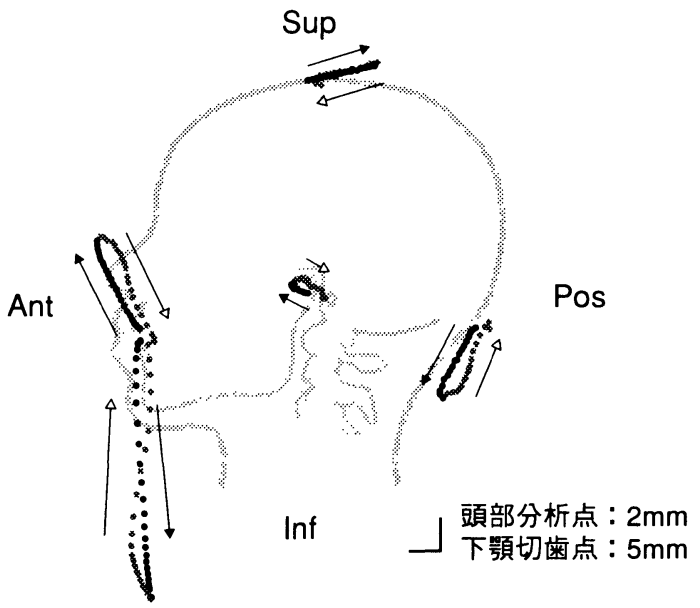

図 5 分析点の運動軌跡の一例 (Sub.B $1 \mathrm{~Hz}$ tapping)

Fig. 5 Sample trace of reference points' movement 


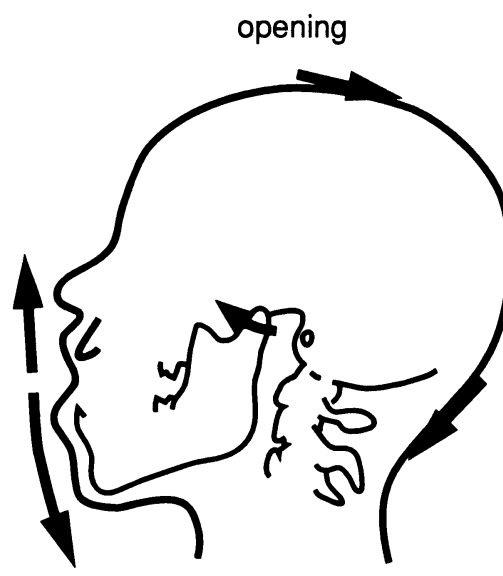

a )

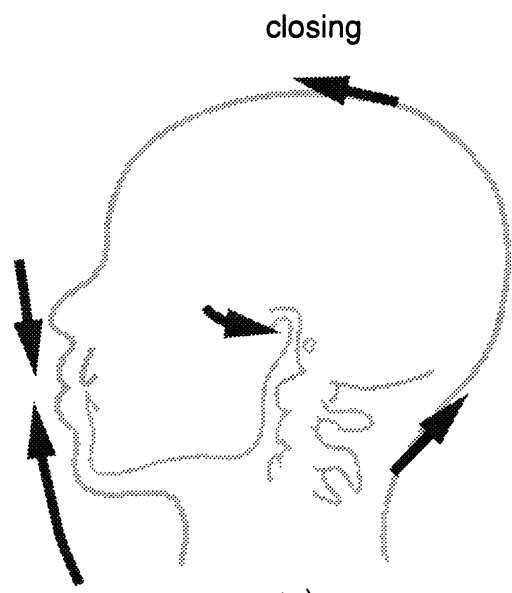

b )

図 6 開閉口運動時の頭部分析点及び下顎切歯点運動経路の模式図
a) 開口時
b) 閉口時

Fig. 6 Direction of reference head points and mandibular incisal point a) opening phase; b) closing phase

された（表 2 ).

\section{2. 頭部分析点の運動}

1) 運動方向 $\theta$ について

開口時の頭部分析点について計測すると，Cでは運動 方向 $\theta$ の平均が-16 32度と前下方から前上方に向かっ

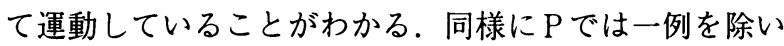
て平均で140～200度とやや広範囲ではあるが，概ね後方 に向かって運動していた，さらにOでは平均-30〜-69度 となり，前下方に運動していることが示された。また， タッピング頻度別に各分析点の運動方向 $\theta$ を比較する と, 全被験者の運動方向 $\theta$ は Student $\mathrm{t}$-検定にて有意差 を認めなかった（表 1$)$.

閉口時における C，P，Oの運動方向はI U， I L と 同様に開口時とは運動方向を逆転して開口運動開始点の 近傍へ戻る運動を行っていることが示された（図 5 ).

2 ) 運動距離 dについて

頻度 $1 \mathrm{~Hz}$ のタッピング運動でCが平均 $2.8 \mathrm{~mm}, \mathrm{P}$ が平 均 $4.5 \mathrm{~mm}, \mathrm{O}$ が平均 $6.4 \mathrm{~mm}, \mathrm{I} \mathrm{U}$ が平均 $7.7 \mathrm{~mm}$ となり C が最も小さく, 次いで $\mathrm{P}, \mathrm{O}$ の順に大きくなっており I Uが最大となった。また頻度 $3 \mathrm{~Hz}$ のタッピング運動時 には C，Pが最小值を示し， O， I Uの順に大きな值を 示した.タッピング頻度別に各分析点の運動距離 $\mathrm{d}$ を比 較すると, 全被験者の運動距離 $\mathrm{d}$ はStudent $\mathrm{t}$-検定にて危 険率 $0.1 \%$ で $1 \mathrm{~Hz}$ の方が有意に大きいことが示された (表 2 ).

\section{3. 頭部全体としての動き}

頭部分析点の運動経路の測定結果から, I U, C , P, Oの 4 点では左側矢状面から観察すると，開口時には時 計回りの，また閉口時には反時計回りの運動を行ってい ることが示された（図 6 )。また，Cでは 4 つの頭部任 意点の中で最小の運動距離を示すことが明らかとなっ た。これらの現象から考えると頭部の運動はCの近傍に に中心を持つ回転様運動を行っていることが示唆されて くる.

\section{IV. 考 察}

\section{1. 研究方法について}

タッピング運動を負荷した頭位はカンペル平面を水平 とした頭位である。この頭位においては下顎のタッピン グ運動経路が他の頭位に比較して安定していることが知 られている7 このことょり今回はカンペル平面を水平と する頭位で運動を記録した。この他の頭位におけるタッ ピング運動に関しては，今後の検討課題となっている.

下顎のタッピング運動は若干の側方偏位を含んでい る。しかし顎口腔系に異常を認めない健常者では，開口 量約 $20 \mathrm{~mm}$ のタッピング運動における上顎切歯点の側方 偏位量は, 開口量の $1.5 \sim 2.7 \%$ と非常に小さい ${ }^{3.41}$. 従 って，矢状面からの二次元的な解析を行うことで頭部運 動の様相が十分把握できると判断した。また，各分析点 の運動経路を矢状面から観察すると，開口路では図 5 に 示すごとく滑らかで直線的な軌跡を描いていることか 


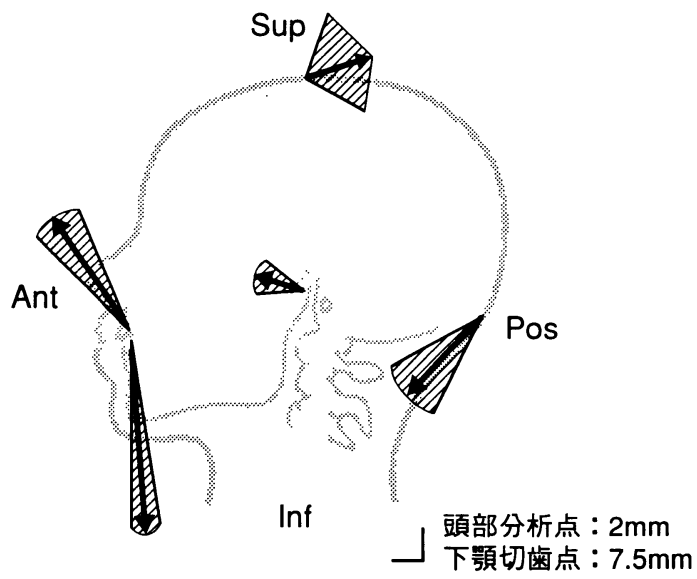

図 7 各分析点における運動方向 $\theta$ の平均, 標準偏差

Fig. 7 Mean and standard deviation of direction in each reference point. Solid arrow: mean; Shaded area: standard deviation

ら,この運動経路について運動方向 $\theta$, 運動距離 $\mathrm{d}$ を計 測することで各分析点の開口時及び閉口時の運動様相を 把握することとした（図 4 ）.

2. 実験結果について

1) 運動方向 $\theta$ について

タッピング頻度別に各分析点の運動方向を比較したと ころ有意差を認めなかった（表 1 )。そこで，各分析点 ごとに，計測した全ての運動における運動方向 $\theta$ の平均 值と標準偏差を表 3 ，図 7 に示す。図 7 に示した各分析 点の矢印は運動方向 $\theta$ の平均を, 斜線で示した範囲はそ の $\pm 1 S D$ 範囲を示す。このことょり，頭部はタッピン グの頻度が $1 \mathrm{~Hz}$ あるいは $3 \mathrm{~Hz}$ にかかわらず回転様の運 動をしていることがわかる.

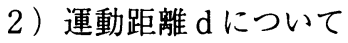

タッピング頻度別の運動距離 $\mathrm{d}$ は全ての分析点におい て全被験者の值で $1 \mathrm{~Hz}$ が $3 \mathrm{~Hz}$ より有意に大きかった。 しかし, 被験者別に, タッピング頻度別の各分析点の運 動距離を比較すると，その比はほほ等倍から 7 倍までと さまざまで，特に被験者 B のCでは，他の部位とは異な り頻度 $3 \mathrm{~Hz}$ の方が運動距離が大きくなる（表 2 ）。この ように頭部分析点の運動距離 $\mathrm{d}$ はタッピング頻度の違い による值の変化に明確な規則をもたず，今回の結果から は不明な点が多かった。このことを明らかにするために は，今後さらなる検討が必要である。

\section{3. 頭部回転中心の検索試行}

表 3 各分析点における運動方向 $\theta$ の平均, 標準偏差

Table 3 Mean and standard deviation of direction in each reference point

\begin{tabular}{crcccc}
\hline & IL & IU & C & P & O \\
\hline mean & -94.7 & 57.3 & 18.1 & 160.3 & -46.5 \\
SD & 3.9 & 10.7 & 21.5 & 48.2 & 17.0 \\
\hline & & & & & 単位:度
\end{tabular}

今回の結果より，頭部が左側面観で開口時に時計回り の運動を，閉口時に反時計回りの運動を行っている事が 明らかとなった。この運動の様相からタッピング運動時 の頭部運動は，回転運動であることが予測される。そこ でこの運動に回転中心が存在するか否かについて，4名 の被験者から 2 名を無作為に選択し，探索を行った。

1) 方 法

タッピング運動において開口時の頭部運動を多点にお いて観察したところ，Cは運動方向がほほ前方であり， 運動距離も短い。一方, 頭部の前方点である I Uの軌跡 は下方から上方へ移動，頭部後方の点では上方から下方 へ移動する軌跡として描かれ，また頭部の上方点では前 方から後方へ移動していることが明らかとなった。この 結果から, 開口時の頭部運動は、Cのやや上方に中心が 存在する回転運動であると推測できる。

そこで，頭部運動の矢状面投影図上において，Cの上 方 $10 \mathrm{~mm}$ の点を中心に $10 \mathrm{~mm}$ 間隔の格子状に 30 点以上の 任意点を設定し、各点の運動軌跡を描記した．描かれた 軌跡のうち最も移動距離が少ない点を中心に，さらに細 かく最小 $2.5 \mathrm{~mm}$ 間隔に格子状の任意点を設定し，任意点 の移動距離が，前後，上下的に最も短く，さらにその前 後，上下で描かれる軌跡が互いに逆向きとなる点を探索 して，その点を頭部の回転運動中心として求めた

このようにして求めた頭部回転中心を側貌 X 線規格写真 をもとに作成した頭部の矢状面図上に重ね合わせて表示 した.

2) 結 果

回転運動中心付近の任意点における開口時の運動軌跡 を描いた例を図 8 に示す。黒い矢印で示した点は図中で 最も移動距離が少なく，その外方にある点は同心円上の 軌跡を描いている。 さらに，その矢印で示した点を挟ん で，前後，上下では白い矢印で示すごとく軌跡の運動方 向が逆転しており，またその軌跡の移動距離は外方に向 かうほど増加している。このことから開口運動時に頭部 は黒い矢印で示した点を中心に回転運動を行っていると 


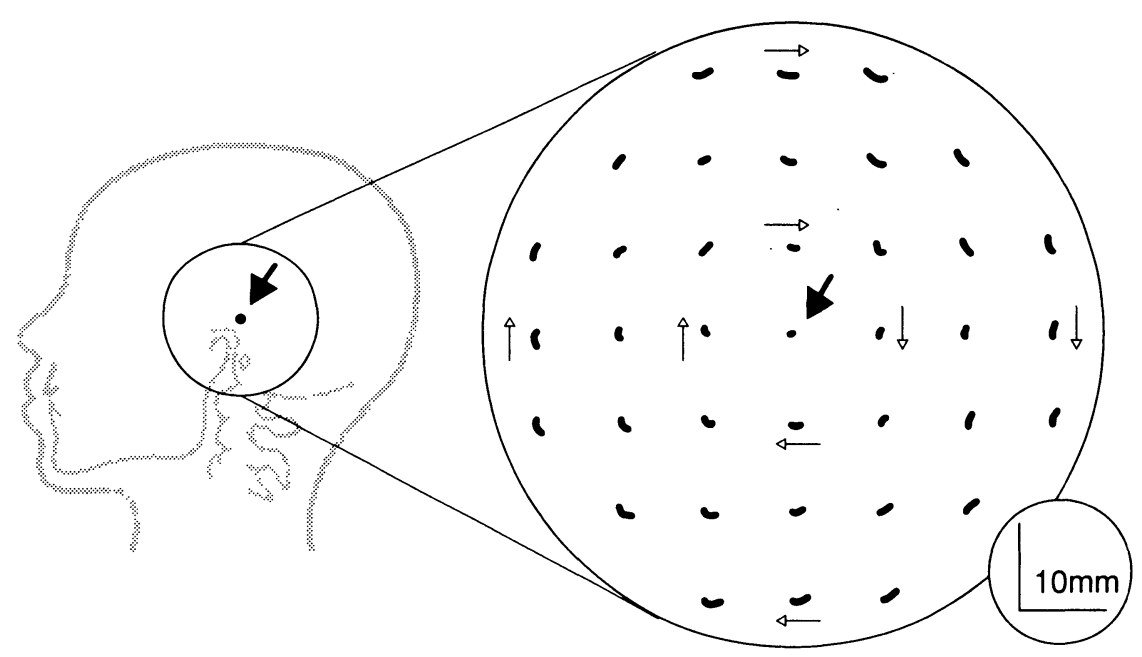

図 8 回転中心の探索

Fig. 8 Determination of the rotation center

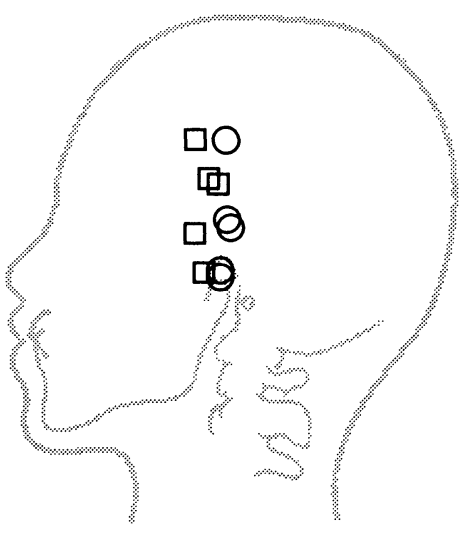

a)

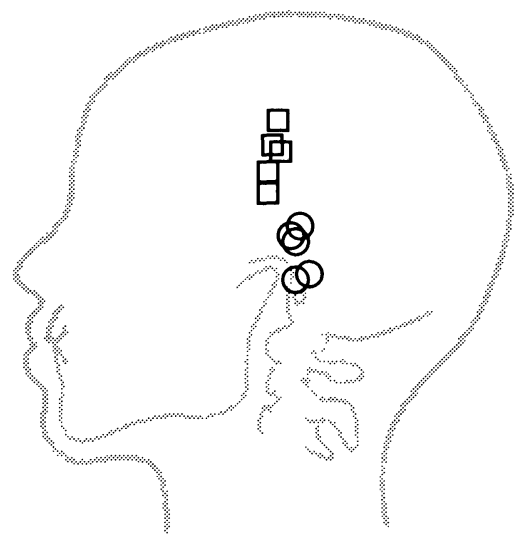

b)

図 9 回転中心の存在位置
a) 被験者A b) 被験者B
$\bigcirc: 1 \mathrm{~Hz} \quad \square: 3 \mathrm{~Hz}$

Fig. 9 Position of rotation center
a) Sub.A
b) Sub.B
$\bigcirc: 1 \mathrm{~Hz} \quad \square: 3 \mathrm{~Hz}$

いえる。

頭部回転運動の中心位置は, 両被験者とも各ストロー クにおいて必ずしも一致しないが, 前後的に大きく変化 することなく，頸椎の上方の体軸上に分布していること が認められた。

また, 被験者Aでは回転中心の位置は $1 \mathrm{~Hz}$ のタッピン グの方が $3 \mathrm{~Hz}$ のタッピングよりも後方, 下方に多く存 在する傾向が認められ，さらに被験者Bでは被験者Aよ りも明確に $3 \mathrm{~Hz}$ の回転中心が上方, $1 \mathrm{~Hz}$ の回転中心が
下方と，分布領域が異なることが示された．

このことは, タッピング頻度の違いが, 頭部回転運動の 中心位置に関係していることを示唆しており，さらに各 分析点の運動距離 $\mathrm{d}$ が異なるタッピング頻度において不 規則な変化をする原因の一つであると考えられる（図 9 ).この点については、タッピング運動の負荷条件を 多方面から考慮して，さらなる詳細な検討が必要と考え ている. 


\section{V. 結 論}

1.タッピング運動の際，矢状面観で，頭部は下顎開口 時に上顎切歯点が下顎切歯点と離れるよう後屈方向 に，閉口時にはこれらが近づくように前屈方向にと回 転運動を行っていることが明らかとなった。

2. 頻度 $1 \mathrm{~Hz}$ のタッピングでは頻度 $3 \mathrm{~Hz}$ のタッピング より各分析点の運動距離は有意に大きいが, 運動方向 に有意差は見られなかった。

3. 頭部回転運動の中心探索の結果, タッピング運動の 開口相において頭部運動の回転中心は，頸椎の上方の 体軸上に分布しており，この位置は夕ッピング頻度と 関係のあることが示唆された。

\section{文献}

1 ) Lund, J.P. and Enomoto, S.: The generation of mastication by the mammalian central nervous system, edited by Cohen, A.H., Rossignol, S. and Grillner, S., Neural con- trol of rhythmic movements in vertebrates, 41-72, Wiley Interscience, New York, 1988.

2 ) 荒井良明, 松山剛士, 河野正司ほか：咀嚼時に観察 される上顎の協調運動記録の試み，顎機能誌， 1 : 183-188, 1994.

3 ）松山剛士, 河野正司, 荒井良明ほか：咀嚼時に観察 される下顎運動と協調した頭部運動, 顎機能誌, $2: 159-165,1996$.

4 ）松山剛士：タッピング運動時に観察される頭部の協 調運動, 補緅誌, $40 ： 535-543 ， 1996$.

5 ）大竹博之, 河野正司, 松山剛士ほか: 顎機能障害症 例に見られる下顎タッピング運動時の頭部運動，顎 機能誌, 3:131-138, 1997.

6 ) 黒川昌彦, 林豊彦, 宮川道夫ほか：1 次元CCD メラを用いた顎運動測定装置（JKN-1）の測定精度, 信学技報, MBE92-96：81-88, 1992.

7 ）池田圭介, 河野正司, 土田幸弘ほか：顆頭安定位の 立場からみたタッピング運動による水平的下顎位の 検索, 補緅誌, 40：964-971, 1996. 